\title{
Cytogenetic Evaluation of the Effects of Chromium and Detergents in Vicia faba
}

\author{
Rafael Villalobos-Pietrini, Ana Rosa Flores-Márquez \\ and Sandra Gómez-Arroyo \\ Laboratorio de Citogenética y Mutagénesis Ambientales, Centro de Ciencias de la \\ Atmósfera, Universidad Nacional Autónoma de México, Coyoacán 04510 \\ D. F., México y Centro de Investigación en Genética y Ambiente, \\ Universidad Autónoma de Tlaxcala, Tlaxcala 90000, México
}

Accepted October 23, 1992

Detergents are a complex group of chemicals used to elaborate diverse washing agents, pesticides, food and pharmaceutical products. On the basis of their ionization in water, they are anionic, cationic or nonionic. The most commonly used are the anionic $(80 \%$ of the detergents), therefore they are also the most important pollutants of the watercourses.

Detergents are amphipathic molecules which are isolated at low concentrations in water, as concentrations increase micelles are formed. There is a critical micelle concentration (CMC) which depends upon the characteristic of the detergent as well as its hydrophobic and hydrophilic parts (Darnell et al. 1990).

On the other hand, the element chromium in very low amounts is useful for organisms but at higher concentrations it is toxic and considered as a pollutant. The hexavalent form, although highly oxidant and readily reducible, has been shown to persist in the environment, specially when conditions (e. g., alkaline $\mathrm{pH}$ values and low organic matter contents) are not favorable for its reduction to the trivalent form (Gutiérrez-Ruíz et al. 1989, 1990). Cr (VI) is the most active biologically, because it is capable of passing through cell membranes (Taylor and Parr 1978) by using the sulfate transport system (Jennette 1981). As the trivalent form does not cross cell membranes it is excluded from the cell (Jennette 1981).

Due to the fact that in many countries, including Mexico, the watercourses with industrial releases have a mixture of metals and detergents (Gutiérrez-Ruíz 1982) and these interact with the living systems, it is important to determine the cytogenetic effects of these mixtures.

\section{Material and methods}

Seedlings of Vicia faba with roots of 4 to $6 \mathrm{~cm}$ in length were utilized. The anionic surfactant was the commercial detergent Roma (La Corona), which is commonly used in Mexico, with $41.9 \%$ of alkyl aryl sodium sulfonate from which concentrations of this active ingredient of $12,120,1200 \mathrm{ppm}$ were used. Triton X-100 (octyl phenoxy polyethoxy ethanol with an average of 10 moles of ethylene oxide) is the nonionic detergent (Rohm and Haas Company 1983) prepared and applied in concentrations of 120,600 and $1200 \mathrm{ppm}$.

Potassium dichromate (Baker) was used only in one concentration ( $500 \mathrm{ppm})$, this was based on the results of previous experiments (Gómez-Arroyo and Villalobos- Pietrini 1983).

The absorbance of the samples of mixtures of potassium dichromate and detergents which showed $\mathrm{pH}$ values above 5, was read in a spectrophotometer. A maximum was found at $479 \mathrm{~nm}$, which remained unchanged throughout the four hours of the experiment, proving that the compounds did not react under these experimental condition. When the $\mathrm{pH}$ was lowered to 1.0 after $24 \mathrm{hr}$, the absorbance values of the mixtures changed continuously, showing that in an acid environment, reactions take place between $\mathrm{Cr}$ (VI) and the detergents, most 
probably of redox type, due to the oxidizing power of $\mathrm{Cr}$ (VI) in acid media.

Four experiments were made: one with groups of seedlings exposed to different detergent concentrations, another treated with potassium dichromate, the third in which chromium and the detergents were mixed. The last one was the control with distilled water. The plants were treated for a duration of four hours and with two hour recovery period in accordance with the former work of Gómez-Arroyo and Villalobos-Pietrini (1983). The meristems were stained with Schiff reagent and after squashing, the slides were made permanent with dry ice, followed by two changes of butanol and mounted in Canada balsam.

In order to verify the c-mitotic effect, as well as the action at the centromeric level, chromosome aberrations were scored in anaphase cells as bridges and fragments. The data tabulated are the results of one experiment and its replica. To compare the frequencies obtained in treated groups with those of the control, the differences of proportions test (Spiegel 1970) was applied.

\section{Results and discussion}

The concentrations used of the Roma and Triton X-100 detergents did not produce chromosomal aberrations nor c-metaphases in numbers significantly different from the controls. Only in the former, at a concentration of $1200 \mathrm{ppm}$ was tissue damage induced (Tables 1,2 ). The data were in agreement with those obtained by Hope (1977) in rats that were fed with anionic detergents which did not have any effects on the chromosomes of bone marrow cells. Tsujii and Tokiwa (1977) noticed a very weak interaction of anionic detergents on the thermal denaturation of DNA.

Table 1. Chromosomal aberrations and c-metaphases induced by the anionic detergent

(Roma), potassium dichromate and mixtures of both substances in meristematic cells of the root tips of Vicia faha.

\begin{tabular}{lcccc}
\hline \multicolumn{1}{c}{ Group } & $\begin{array}{c}\text { Total } \\
\text { anaphases }\end{array}$ & $\begin{array}{c}\text { Chromosomal } \\
\text { aberrations** } \\
\overline{\mathrm{X}} \pm \text { S. D. }\end{array}$ & z value & c-metaphases \\
\hline Control & 7638 & $0.46 \pm 0.16$ & & - \\
Detergent $(12 \mathrm{ppm})$ & 2794 & $0.59 \pm 0.13$ & -0.84 & - \\
Detergent $(120 \mathrm{ppm})$ & 3027 & $\begin{array}{c}0.50 \pm 0.15 \\
\text { Tissue damaged }\end{array}$ & -0.27 & - \\
$\begin{array}{l}\text { Detergent }(1200 \mathrm{ppm}) \\
\text { Potassium dichromate }(500 \mathrm{ppm})\end{array}$ & 1326 & $5.69 \pm 0.23$ & $-15.96^{*}$ & + \\
$\begin{array}{l}\text { Detergent }(12 \mathrm{ppm}) \text { plus } \\
\text { Potassium dichromate }(500 \mathrm{ppm})\end{array}$ & 1639 & $7.40 \pm 1.14$ & $-19.85^{*}$ & + \\
$\begin{array}{l}\text { Detergent }(120 \mathrm{ppm}) \text { plus } \\
\text { potassium dichromate }(500 \mathrm{ppm})\end{array}$ & 1571 & $5.68 \pm 0.75$ & $-16.36^{*}$ & + \\
\hline
\end{tabular}

* $\mathrm{P}<0.001$, significance was set at 0.001 with a $\mathrm{z}$ value of 329

** /100 anaphases

Physiologically, the detergent Roma, although it produced a higher food assimilation in carps with increasing concentrations, it caused an assimilation rate $30 \%$ less than in the control (Espina et al. 1986). Triton X-100 induced weight gain in mice (Kaneene and Ross 1986) and inhibited the growth of fresh water and marine algae (Nyberg 1985).

Potassium dichromate induced chromosomal aberrations well above control frequencies (Tables 1,2) which was in agreement with the results obtained by Gómez-Arroyo and Villalobos-Pietrini (1983) in Vicia faba. Splindle disturbances were also observed which were expressed as c-metaphases, and have already been described by Levan (1945) in meristematic cells of Allium cepa. This $\mathrm{Cr}$ (VI) gived clear positive chromosomal damage in numerous 
experimental test systems (Villalobos-Pietrini 1977, de Flora et al. 1990) specially those related with the availability of $\mathrm{Cr}$ to the cells.

Once $\mathrm{Cr}$ (VI) has been taken up by the cells, a series of cytoplasmic electron donors and also microsomal and mitochondrial enzymes tend to reduce it to Cr (III) (de Flora et al. 1990), the form in which it binds to DNA, mainly to puric bases (Tsapakos and Wetterhahn 1983).

The mixtures of chromium and detergents induced chromosomal aberrations in frequencies statistically different from the controls but not different from the chromium groups treated. Also c-metaphases were observed (Tables 1,2) in both groups but the surfactants did not facilitate the chromium genotoxicity as could be expected. These results are in agreement with the lack of facilitation of cadmium transference to the gills of rainbow trout (Salmo gairdneri) in the presence of detergents (Pärt et al. 1985). Calamari and Marchetti (1973) found a "more than additive" toxic effect of mixtures of copper and mercury with anionic surfactants in rainbow trout, but it was "less than additive" when the combination was made with nonionic detergents. The same result was observed by Bianucci and Legnani (1973) in the fish Alburnus alburnus with an anionic detergent, but in lower concentrations the results were antagonistic.

On the other hand, the toxicity of copper and cadmium in the algae Chlorella, was synergistic in the presence of Triton X-100 (Wong 1985); also the same synergistic toxic effect was produced by cadmium with the linear alkyl bencene sulphonate in the freswater fish Puntius gonionotus Blecker (Jangchudjai et al. 1987).

Table 2. Chromosomal aberrations and c-metaphases produced by nonionic detergent (Triton $\mathrm{X}-100$ ), potassium dichromate and mixtures of both in meristematic cells of the root tips of Vicia faba.

\begin{tabular}{lcccc}
\hline \hline \multicolumn{1}{c}{ Group } & $\begin{array}{c}\text { Total } \\
\text { anaphases }\end{array}$ & $\begin{array}{c}\text { Chromosomal } \\
\text { aberrations** } \\
\overline{\mathrm{X}} \pm \mathrm{S} \text {. D. }\end{array}$ & z value & c-metaphases \\
\hline Control & 8724 & $0.56 \pm 0.15$ & & - \\
Detergent $(120 \mathrm{ppm})$ & 1968 & $0.82 \pm 0.19$ & -1.35 & - \\
Detergent $(600 \mathrm{ppm})$ & 4211 & $0.59 \pm 0.39$ & -0.22 & - \\
Detergent $(1200 \mathrm{ppm})$ & 4045 & $0.57 \pm 0.28$ & -0.06 & - \\
Potassium dichromate $(500 \mathrm{ppm})$ & 2574 & $5.90 \pm 0.73$ & $-18.10^{*}$ & + \\
$\begin{array}{l}\text { Detergent }(120 \mathrm{ppm}) \text { plus } \\
\text { potassium dichromate }(500 \mathrm{ppm})\end{array}$ & 1921 & $6.68 \pm 1.78$ & $-19.07^{*}$ & + \\
$\begin{array}{l}\text { Detergent }(600 \text { ppm) plus } \\
\text { potassium dichromate }(500 \mathrm{ppmi})\end{array}$ & 2415 & $5.65 \pm 0.74$ & $-17.36^{*}$ & + \\
$\begin{array}{l}\text { Detergent }(1200 \text { ppm) plus } \\
\text { potassium dichromate }(500 \mathrm{ppm})\end{array}$ & 982 & $5.52 \pm 1.92$ & $-14.38^{*}$ & + \\
\hline
\end{tabular}

* $\mathrm{P}<0.001$, significance was set at 0.001 with a $\mathrm{z}$ value of 3.29

**/100 anaphases

From the above discussion it is clear that the interaction of metals-detergents in organisms is very wide. In this work the results were similar for both anionic and nonionic detergents, in spite of the findings of Ooshima et al. (1986) that nonionic surfactants hydrolized cellulose by enzymatic saccharification to glucose while anionic surfactants did not.

The concentrations of the two detergents applied were around the $\mathrm{CMC}$ but they were also applied at lower and higher concentrations. The CMC for Roma detergent is $400-600 \mathrm{ppm}$ and for Triton X-100 is around $150 \mathrm{ppm}$ (Nyberg 1985). At concentrations above CMC, the nonionic surfactants solubilized the biological membranes by forming mixed micelles of detergents, proteins and lipids but at low concentrations they did not denature proteins but did solubilize most membrane proteins (Darnell et al. 1990). The anionic surfactants at high concentrations denaturate proteins binding to the hydrophobic portion, affect the conformations of the hydrophilic regions and disrupt ionic and hydrogen bonds (Darnell et al. 1990). 
The general conclusion of the findings of this work is that detergents, independently of whether or not they are anionic or nonionic, did not facilitate the genotoxic effects of hexavalent chromium.

\section{Summary}

The clastogenic effect of two detergents one anionic (Roma) and another nonionic (Triton $\mathrm{X}-100)$, potassium dichromate, and various concentrations of the mixtures metal-detergents was analyzed in the meristematic cells of the root tips of Vicia faba. The chromium compound induced chromosomal aberrations as well as c-metaphases in similar frequencies as the mixture chromium- surfactants. The detergents did not produce cytogenetic disturbances, nor did they facilitate the clastogenic effects of chromium.

Key words: Vicia faba; detergents; surfactants; chromium; potassium dichromate; clastogenic effects; cytogenetic effects; chromosomal aberrations; c-metaphases.

\section{Acknowledgments}

The authors thank the technical assistance of Miguel Angel Meneses, Josefina Cortés and Edgar Villarruel.

\section{References}

Bianucci, F. and Legnani, P. 1973. Richerche sulla tossicitá di miscele di cromo-detergente anionico per l' "Alburnus alburnus" varieta "alborella". Ligiene Moderna 6: 1-7.

Calamari, D. and Marchetti, R. 1973. The toxicity of mixtures of metals and surfactants to rainbow trout (Salmo gairdneri Rich.). Water Res. 7 : 1453-1464.

Darnell, J., Lodish, H. and Baltimore, D. 1990. Molecular Cell Biology. Scientific American Books. New York. pp. 504-505.

de Flora, S., Bagnasco, M., Serra D. and Zanacchi, P. 1990. Genotoxicity of chromium compounds. A review. Mutat. Res. 238: 99-172.

Espina, S., Diaz F., Rosas, C. and Rosas, I. 1986. Influencia del detergente sobre el balance energetico del Ctenopharyngodon idella a traves de un bioensayo cronico. Contam. Ambient 2: 25-37.

Gómez-Arroyo, S. and Villalobos-Pietrini, R. 1983. Chromosomal alterations induced by some chromium salts. Cytologia 48: 185-193.

Gutiérrez-Ruiz, M. 1982. Estudio del contenido de iones inorgánicos y sus interacciones en suelos y plantas de los distritos de riego 03 y 88 . Tesis de Maestría, Facultad de Química, UNAM México, D. F.

Gutiérrez-Ruiz, M. E., Castillo-Blum S. E. and Rosales-Aguilera E. 1989. Chromate contamination north of Mexico Cty: Proposal for a solution. Industry and Environment 12: 51-56.

-, Villalobos-Peñalosa M. and Miranda J. A. 1990. Chromium pollution evaluation in groundwaters of north Mexico City. Rev. Int. Contam. Ambient. 6: 5-18.

Hope, J. 1977. Absence of shromosome damage in the bone marrow of rats fed detergent actives for 90 days. Mutat. Res. 56: 47.-50.

Jangchudjai, C., Upatham, E. S., Duangsawasdi, M. and Kiravanich, P. 1987. Acute toxicity of the synergism of surfactant (LAS) and copper on the freshwater fish, Puntius gonionorus, Bleeker. J. Sci. Soc. Thailand 13: $159-167$.

Jennette, K. W. 1981. The role of metals in carcinogenesis: biochemistry and metabolism. Environ. Health Perspect. 40: 223-252.

Kaneene, J. B. and Ross, R. W. 1986. Effect of surfactants on weight gain in mice. Vet. Res. Commum. 10: $157-164$.

Levan, A. 1945. Cytological reactions induced by inorganic salt solutions. Nature 156: 751-752.

Nyberg, H. 1985. Physiological effects of four detergents on the algae Nitzschia actinastroides and Porphyridium purpureum. Publ. Dept. Bot. Univ. Helsinki 12: 1-77.

Ooshima, H., Sakata, M. and Harano, Y. 1986. Enhancement of enzymatic hydrolysis of cellulose by surfactant. Biotech. Bioengin. 28: 1727-1734. 
Pärt, P., Svanberg, O. and Bergström, E. 1985. The influence of surfactants on gill physiology and cadmium uptake in perfused rainbow trout gills. Ecotoxicol. Environ. Safety 9: 135-144.

Rohm and Haas Company. 1983. Triton X-100 nonionic surfactant. Supersedes CS-427 7/82.

Spiegel, M. R. 1970. Statistics. Schaum's outline series, Schaum Publishing, New York. pp. 142-143.

Taylor, F. G. and Parr, P. D. 1978. Distribution of chromium in vegetation and small mammals adjacent to cooling towers. J. Tenn. Acad. Sci. 53: 87-91.

Tsapakos, M. J. and Wetterhahn, K. E. 1983. The interaction of chromium with nucleic acids. Chem. Biol. Interact. 46: 265-277.

Tsujii, K. and Tokiwa, F. 1977. Effects of surface-active compounds on thermal-denaturation of DNA. J. Amer. Oil Chem. Soc. 54: 585-586.

Villalobos-Pietrini, R. 1977. Efectos biológicos del cromo. An. Inst. Biol. Univ. Nal. Auton. Mex. 48, Ser. Biol. Exp. 115-162.

Wong, S. L. 1985. Algal assay evaluation of trace contaminants in surface water using the nonionic surfactant, Triton X-100. Aquat. Toxicol. 6: 115-131. 